\title{
Efeito da aclimatização no reconhecimento de fala: avaliação sem as próteses auditivas $* * * *$
}

\author{
Acclimatization effect in speech recognition: evaluation without \\ hearing aids
}

\author{
Sinéia Neujahr dos Santos* \\ Tiago Petry** \\ Maristela Julio Costa***
}

\begin{abstract}
*Fonoaudióloga. Mestre em Distúrbios da Comunicação Humana pela Universidade Federal de Santa Maria (UFSM). Fonoaudióloga Clínica da Sonora - Centro de Audiologia e Adaptação de Próteses Auditivas Santa Maria - RS. Endereço para correspondência: Av. Dois de Novembro, 1414 - Apto. 303 - Santa Maria - RS - CEP 97020-230 (sineians@gmail.com).
\end{abstract}

**Fonoaudiólogo. Mestre em Distúrbios da Comunicação Humana pela UFSM. Fonoaudiólogo Perito Criminal do Instituto Geral de Perícias - Florianópolis - SC.

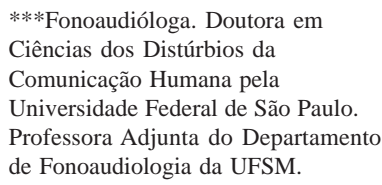

****Trabalho Realizado no Laboratório de Próteses Auditivas do Serviço de Atendimento

Fonoaudiológico da UFSM.

Artigo Original de Pesquisa

Artigo Submetido a Avaliação por Pares

Conflito de Interesse: não

Recebido em 10.11.2009.

Revisado em 10.10.2010.

Aceito para Publicação em 24.11.2010.

\begin{abstract}
Background: after the adaptation of hearing aids, an improvement in speech understanding is expected to occur, called acclimatization. Aim: to determine the effect of acclimatization in sentences recognition threshold, for the conditions of silence (SRTQ) and noise (SRTN), in new users of hearing aids, evaluated prior to and after acclimatization, without the use of the hearing aids. Method: participants were 40 individuals, aged between 28 and 78 years, with mild to moderate sensorineural hearing loss. Tests were conducted in three sessions: prior to the adaptation of the hearing aids, fourteen days and three months later.The Portuguese Sentences Lists test in free field was used for testing, and the SRTQ and SRTN were obtained (with noise level settled at $65 \mathrm{~dB}$ A). Results were expressed through the signal/noise ratios. Results: the mean values for the SRTQ in the 1st, 2nd and 3rd sessions were 54.43, 51.71 and $52.22 \mathrm{~dB}$ A respectively,. The mean signal/noise ratios for the 1st, 2nd and 3rd sessions were 1.67, 0.30 and -0.03 $\mathrm{dB}$ A. When comparing the results obtained between the testing sessions, a statistically significant difference was observed between the 1st and 2nd sessions, and between the 1st and 3rd sessions for the values obtained in the testing conditions of silence and noise. Conclusion: There was a progressive reduction of sentences recognition thresholds and signal/noise ratios indicating an improvement in performance even when assessing the individuals without the hearing aids. This improvement can be related to the effect of acclimatization.
\end{abstract}

Key Words: Hearing Aids; Acclimatization; Speech Discrimination Tests; Hearing Loss; Neuronal Plasticity.

\section{Resumo}

Tema: após a adaptação das próteses auditivas, espera-se que ocorra uma melhora na compreensão de fala, chamada de aclimatização. Objetivo: verificar o efeito da aclimatização no limiar reconhecimento de sentenças no silêncio (LRSS) e no ruído (LRSR), em novos usuários de próteses auditivas, avaliados antes e após o período de aclimatização, sem a utilização das mesmas. Método: foram avaliados 40 indivíduos, com idades entre com 28 e 78 anos, com perda auditiva neurossensorial de grau leve a moderadamente severo. Os testes foram realizados em três sessões: antes da adaptação das próteses auditivas, quatorze dias e três meses após. Foi aplicado o teste Listas de Sentenças em Português, em campo livre, e obtidos os LRSS e os LRSR, este com ruído fixo a 65 dB A e os resultados expressos através das relações S/R. Resultados: os valores médios obtidos para o LRSS na primeira, segunda e terceira sessões foram, respectivamente, 54,43; 51,71 e 52,22 dB A. Já as médias das relações sinal / ruído para a primeira, segunda e terceira sessões foram 1,67; 0,30 e -0,03 dB A. Ao comparar os resultados obtidos entre as sessões, foi verificada diferença estatisticamente significante entre a primeira e a segunda; e entre a primeira e a terceira sessão, para as medidas obtidas no silêncio e no ruído. Conclusão: Observou-se redução progressiva dos LRSS e relações sinal / ruído, indicando melhorara no desempenho ao longo do uso das próteses auditivas, mesmo avaliando os indivíduos sem as mesmas e que essa melhora pode estar relacionada ao efeito da aclimatização.

Palavras-Chave: Auxiliares de Audição; Aclimatação; Testes de Discriminação da Fala; Perda Auditiva; Plasticidade Neuronal.

Referenciar este material como:

Santos SN, Petry T, Costa MJ. Acclimatization effect in speech recognition: evaluation without hearing aids (original title: Efeito da aclimatização no reconhecimento de fala: avaliação sem as próteses auditivas). Pró-Fono Revista de Atualização Científica. 2010 out-dez;22(4):543-8. 


\section{Introduction}

The effects caused by the difficulty in hearing may be reduced with the adaptation of hearing aids in most cases. In the cases in which the medical or surgical treatment does not reverse hearing loss, the use of hearing aids is the best alternative to reduce the damage and help people to hear and understand the world of sound in a better way1.

After the adaptation of hearing aids, not only an improvement in the perception of sounds because of amplification is expected, but also an improvement in speech comprehension, which is called acclimatization. This stimulus will promote neural plasticity and allow the central auditory pathways to reorganize and produce positive effects in hearing abilities2.

Acclimatization has been studied in several researches, but many of them with the objective of analyzing the benefits provided by hearing aids both during and after this period, but these studies usually made evaluations in the subjects only with the use of hearing aids1,3-11. However, if acclimatization really occurs, it is possible that these subjects improve speech recognition, even if they are evaluated without using these aids7.

Therefore, tests that use sentences as a stimulus to evaluate the ability of hearing aids users to recognize speech in situations that represent circumstances of everyday communication have been increasingly used, as they can identify the real condition of individuals in a situation of communication, and may be applied with different objectives.

Thus, this study aims at verifying the acclimatization effect on sentence recognition in quiet and in noise in users of hearing aids who were evaluated before and after the acclimatization period, without hearing aids.

\section{Method}

The study was accomplished at the Laboratory of Hearing Aids of the Speech Therapy Service at the Federal University of Santa Maria. This research is registered in the Gabinete de Projetos under number 019731 and approved by the Research Ethics Committee under number 0138.0.243.000-06.

Only individuals who agreed to participate in the research took part in the study, and signed the Free and Informed Consent Term after they received information about it.
The criteria for including the group of subjects in the research were: to be aged 18 or more, to present sensorineural hearing loss from mild to moderate-severe, to have speech recognition threshold (SRT) of no more than $65 \mathrm{~dB}$ NA, to be a new user of hearing aids, to be part of the Program of hearing aids donation of the Federal Government, and not to present any aspect that could interfere in the test, such as neurological and/or verbal fluency alterations.

Approximately 200 individuals were evaluated from January 2008 to January 2009, of which 47 were selected and 40 finished all the evaluations. Their ages ranged from 28 to 78, and there were 23 women and 17 men.

After the basic audiological evaluation, the individuals underwent the research of the Sentence Recognition Thresholds in Quiet (SRTQ) and in Noise (SRTN), in free field. The tests were made without using the hearing aids, in different evaluation sessions, and consisted of three sessions for each subject. The first evaluation was made before the adaptation of the hearing aids, the second one fourteen days after the adaptation and the third one, three months after the adaptation.

The SRTQ and the SRTN were obtained by using the Portuguese Sentences Lists test (PSL)13, which consists of a list with 25 sentences, another list with 10 sentences, and a noise with a speech spectrum14. The sentences and the noise were copied onto CD, in independent channels.

The measurements were obtained in an acoustically treated booth, by using a digital twochannel audiometer, Damplex brand, model DA65, with an amplification system for free-field audiometry, model TA 1010, and a CD player, Britânia brand, model B5279, in the lineout option attached to the audiometer.

The technique for presentation of the sentences was based on the sequential or adaptive strategy, ascending-descending15.

The procedure for the research of the SRTQ and the SRTN consisted of the presentation of a stimulus in certain intensity, approximately $10 \mathrm{~dB}$ above the SRT. The SRTN was researched with a constant intensity of noise, at $65 \mathrm{~dB}$. Intervals of $4 \mathrm{~dB}$ were used until the first change in the type of response, and then the intervals of stimuli presentation started to be $2 \mathrm{~dB}$ until the end of the list.

For the calibration of the channel of the sentences, a pure tone in the first CD track (channel 1 ) was used as a reference, and the noise was 
calibrated the same way, since it is a continuous sound, on channel 2. The output of each channel was calibrated by the VU-meter of the audiometer. Both the pure tone, on channel 1, and the noise, on channel 2, were put in the zero level.

However, it is important to note that it was observed in a previous study7 that the sentences were copied onto $\mathrm{CD}$ at an average intensity of $7 \mathrm{~dB}$ below the intensity of the pure tone. Thus, for each measurement obtained in free field using the pure tone as a reference, $7 \mathrm{~dB}$ should be subtracted from this value to interpret the values of speech presentation. In turn, the channel of the noise was calibrated by using the same noise, which was recorded on channel 2, therefore with no correction to be made

The variables considered in this study were SRTQ and SRTN, the last one expressed by the S/ $\mathrm{N}$ ratio, which s the difference between the average intensity of the presentation of the sentences and the noise (65 dB SPL - A).

Having established the normal distribution of the data, the paired t test was applied for the difference between two dependent samples, which verifies if the differences found between the evaluation periods were significant or not. There was also a descriptive analysis of the data, which exposes the results between the evaluation sessions.

The variables were compared in pairs, in different sessions of evaluation: first session before the adaptation of the hearing aids, second session - fourteen days after the adaptation of the hearing aids and third session - three months after the adaptation of the hearing aids. It was considered as a relevant result $\mathrm{p}<0,05$, marked with an asterisk (*).

\section{Results}

Table 1 presents the average, the standard deviation, the maximum value, the minimum value and the results of the paired test between the sessions of evaluation, both for the variable SRTQ and for SRTN in the $\mathrm{S} / \mathrm{N}$ ratio.

Table 2 shows the percentage of individuals who presented improvements and the values of the improvements between the evaluations.

TABLE 1. Average, Standard Deviation, minimum and maximum values and result of the paired t test between the sessions of evaluation, for SRTQ and Signal-to-Noise (S/N) ratio, in decibels $(\mathrm{dB})$.

\begin{tabular}{|c|c|c|c|c|c|c|}
\hline Variables & Session & Average & SD & Min & $\operatorname{Max}$ & p Value \\
\hline SRTQ & $\begin{array}{l}1^{\text {st }} \\
2^{\text {nd }}\end{array}$ & $\begin{array}{l}54,43 \\
51,71\end{array}$ & $\begin{array}{l}7,67 \\
8,26\end{array}$ & $\begin{array}{l}41,00 \\
36,00\end{array}$ & $\begin{array}{l}69,67 \\
66,00\end{array}$ & $0,0058^{\star}$ \\
\hline SRTQ & $\begin{array}{l}2^{\text {nd }} \\
3^{\text {rd }}\end{array}$ & $\begin{array}{l}51,71 \\
52,22\end{array}$ & $\begin{array}{l}8,26 \\
8,23\end{array}$ & $\begin{array}{l}36,00 \\
37,00\end{array}$ & $\begin{array}{l}66,00 \\
66,33\end{array}$ & 0,2750 \\
\hline SRTQ & $\begin{array}{l}1^{\text {st }} \\
3^{\text {rd }}\end{array}$ & $\begin{array}{l}54,43 \\
52,22\end{array}$ & $\begin{array}{l}7,67 \\
8,23\end{array}$ & $\begin{array}{l}41,00 \\
37,00\end{array}$ & $\begin{array}{l}69,67 \\
66,33\end{array}$ & $0,0073^{\star}$ \\
\hline $\mathrm{S} / \mathrm{N}$ ratio & $\begin{array}{l}1^{\text {st }} \\
2^{\text {nd }}\end{array}$ & $\begin{array}{l}1,67 \\
0,30\end{array}$ & $\begin{array}{l}3,46 \\
3,42\end{array}$ & $\begin{array}{l}-5,78 \\
-5,33\end{array}$ & $\begin{array}{l}8,67 \\
8,00\end{array}$ & $0,0001^{*}$ \\
\hline $\mathrm{S} / \mathrm{N}$ ratio & $\begin{array}{l}2^{\text {nd }} \\
3^{\text {rd }}\end{array}$ & $\begin{array}{l}0,30 \\
-0,03\end{array}$ & $\begin{array}{l}3,42 \\
3,94\end{array}$ & $\begin{array}{l}-5,33 \\
-7,72\end{array}$ & $\begin{array}{l}8,00 \\
8,78\end{array}$ & 0,2597 \\
\hline $\mathrm{S} / \mathrm{N}$ ratio & $\begin{array}{l}1^{\text {st }} \\
3^{\text {rd }}\end{array}$ & $\begin{array}{l}1,67 \\
-0,03\end{array}$ & $\begin{array}{l}3,46 \\
3,94\end{array}$ & $\begin{array}{l}-5,78 \\
-7,72\end{array}$ & $\begin{array}{l}8,67 \\
8,78\end{array}$ & $0,0013^{*}$ \\
\hline
\end{tabular}


TABLE 2. Percentage of subjects who improved and the improvement values between the evaluation sessions of SRTQ and Signal-to-Noise (S/N) ratio

\begin{tabular}{llcc}
\hline Variables & $\mathbf{N}$ & Improvement (\%) & Improvement Average (dB) \\
\hline $1^{\text {st }}$ SRTQ $\times 2^{\text {nd }}$ SRTQ & 32 & 80 & 3,82 \\
$2^{\text {nd }}$ SRTQ X 3 $3^{\text {rd }}$ SRTQ & 20 & 50 & 2,97 \\
$1^{\text {st }}$ SRTQ X $3^{\text {rd }}$ SRTQ & 33 & 82,5 & 4,00 \\
$1^{\text {st }}$ S/N ratio X $2^{\text {nda }}$ S/N ratio & 30 & 75 & 2,10 \\
$2^{\text {nd }}$ S/N ratio $\times 3^{\text {rd }}$ S/N ratio & 23 & 57,5 & 2,59 \\
$1^{\text {st }}$ S/N ratio X $3^{\text {rd }}$ S/N ratio & 27 & 67,5 & 3,59 \\
\hline
\end{tabular}

\section{Discussion}

By observing the results shown by Tables 1 and 2, it is possible to see that the values found for the SRTQ and the S/N ratios in the second and third evaluations were better than the ones in the first evaluation, in which the subject was not wearing the hearing aids, which shows an improvement in his/her performance.

By comparing the results obtained between the sessions, there was a statistically significant difference between the first one and the second one; and also for the first and the third sessions, both for the measurements obtained in silence and in noise (Table 1).

In the analysis of the percentage of individuals who presented changes between the sessions of evaluations, it was observed for the SRTQ that $80 \%$ of the subjects improved between the first and the second session; $50 \%$ between the second and the third ones; and 82,5\% between the first and the second ones. As to the $\mathrm{S} / \mathrm{N}$ ratios, it was found that $75 \%$ of the subjects presented improvements between the first and the second session; 57,5\% between the second and the third ones; and $67,7 \%$ between the first and the third one (Table 2).

Therefore, it was possible to observe that the significance values and the highest percentages of the subjects who improved from one session to the other, both in quiet and in noise, occurred between the first and the second sessions and between the first and the second session of evaluation.

The results found between the first and the second evaluations suggest that the individuals benefit from the auditory stimulation provided by hearing aids with two weeks of use, but this could not be effect of acclimatization, as this phenomenon occurs in a minimum period of one month using hearing aids3. The better performance could be due to the spontaneous learning of the individual when using the new acoustic information or his/her enthusiasm to the possible benefits provided by hearing aids9.

Although there was a significant difference in the results with only fourteen days using hearing aids, our findings do not agree with the literature36 , which may be due to the short period between the first and the second sessions. Besides, it is possible that the individuals presented a better performance because of familiarity with the procedures, memorization, learning, or even tranquility for having already undergone the test, despite the fact that none of the lists of sentences were repeated in the same situation.

According to some studies, acclimatization does not occur immediately, but only after exposition to the acoustic environment, as the brain needs some time to use the new acoustic information provided by the hearing aid4,7.

In a research, it was observed that speech comprehension in quiet improved even without the use of hearing aids during the evaluation. As to the comparison of the values before and after the adaptation, there was a significant improvement in the scores of speech recognition after two weeks using the aids and after six months of use. The improved performance after two weeks of use was explained by effects of familiarization with the test and not by the effects of acclimatization8.

Therefore, we could attribute the improved results between the first and the third evaluation session to the auditory perceptual acclimatization. The use of aids reintroduced the auditory stimulation from amplification, which reorganized the auditory pathways, resulting in possible improvements in the reception and organization of sound stimuli. This may cause in an improvement in speech recognition over time9-10. The acclimatization would be progressive and the result 
of better use of acoustic cues provided by the use of hearing aids3.

According to some researchers11, the improvement in performance is not related to the change in acoustic information available for the user of the aid, but to the ability to process and discriminate acoustic information, which could be related to an improvement of memory abilities and attention in quiet situations; and memory, selective attention and auditory figure-ground in situations with competing noise, which are hearing abilities involved in speech recognition18.

By analyzing the subjects that improved their performance between the evaluations, we found average improvement values for the SRTQ of 3,82 $\mathrm{dB}$ between the first and the second sessions; 2,97 $\mathrm{dB}$ between the second and the third ones; and $4,00 \mathrm{~dB}$ between the first and the third ones. As to situations with competing noise, the improvement of the $\mathrm{S} / \mathrm{N}$ ratios was $2,10 \mathrm{~dB}$ between the first and the second sessions; 2,59 $\mathrm{dB}$ between the second and the third ones and 3,59, between the first and the third ones.

The highest improvement values occurred between the first and the third sessions, both in quiet and in noise. These results confirm the findings about the period in which the acclimatization effect occurs. According to some studies, acclimatization may occur after approximately three months after the adaptation of hearing aids4-5. However, other researchers say that it may occur six months after the adaptation8, vary between one month and a half and three months after the use of amplification6, or even from the first month of adaptation3.

It was observed that the highest improvement value for the SRTQ was 4,00 dB between the first and the third evaluation sessions. This difference reveals that the individuals were able to recognize $50 \%$ of the speech stimuli with less intensity, even when the hearing aids were not being used. This improvement will help in situations in which the

\section{References}

1. Bucuvic EC, Iório MCM. Benefícios e dificuldades auditivas: um estudo em novos usuários de prótese auditiva após dois e seis meses de uso. Fono Atual. 2004; 29(7):19-29.

2. Arlinger S, Gatehouse S, Bentler RA, Byrne D, Cox RM, Dirks DD, et al. Report of the Eriksholm workshop on auditory deprivation and acclimatization. Ear Hear. 1996; 17(3):8790 . speech stimulus is week or distant, which is a frequent complaint in individuals with hearing loss.

As to the $\mathrm{S} / \mathrm{R}$ relation, the highest improvement value, which was also found between the first and the second evaluation sessions, was 3,59 dB. This value in situations of noise is expressive, because according to many studies, a change of $1 \mathrm{~dB}$ in the $\mathrm{S} / \mathrm{N}$ ratios may cause a variation in speech recognition of $18 \%$ or even $20 \% 20$.

In a research21 that used the PSL 13 test with a methodology similar to the one used in this study, a change of $1 \mathrm{~dB}$ in the $\mathrm{S} / \mathrm{R}$ relation in individuals with sensorineural hearing loss resulted in a change of $11,2 \%$ in speech intelligibility.

Thus, the performance of $3,59 \mathrm{~dB}$ found in this research denotes a percentage of improvement of $40,21 \%$ in the individuals' speech recognition, after the use of hearing aids, even when they were evaluated without them.

Since the main complaints related to the routine of individuals with hearing loss are mainly associated with noisy environments, our findings suggest that, approximately three months after the use of hearing aids those complaints could be minimized.

It was found that with the use of hearing aids during the period mentioned above, there was an improvement in speech recognition because of the stimulation provided by them.

\section{Conclusion}

It is possible to conclude that the individuals improved their performance every evaluation, even without the hearing aids. The significance levels, the amount of individuals who presented improvements and the highest improvement values were predominantly observed between the first and the third evaluation sessions. This shows that the effect provided by acclimatization can occur in a period of approximately three months after the adaptation.
3. Soncini F, Costa MJ, Oliveira TMT. Queixa de dificuldade para reconhecer a fala $\mathrm{X}$ limiares de reconhecimento de fala no ruído em normo-ouvintes com mais de 50 anos. Fono Atual. 2003;26(3):4-11.

4. Costa MJ. Lista de sentenças em português: apresentação e estratégias de aplicação na audiologia. Santa Maria: Pallotti; 1998. p. 26-36. 
5. Costa MJ, Iorio MCM, Albernaz PLM. Desenvolvimento de um teste para avaliar a habilidade de reconhecer a fala no silêncio e no ruído. Pró-Fono. 2000;12(2):9-16.

6. Levitt $\mathrm{H}$, Rabiner LR. Use of a sequencial strategy in intelligibility testing. J. Acoust. Soc. Am. 1967;42(3):609-12.

7. Cóser PL, Costa MJ, Cóser MJ, Fukuda Y. Reconhecimento de sentenças no silêncio e no ruído em portadores de perda auditiva induzida pelo ruído. Revs Bras Otorrinolaringol. 2000;66(4):36270.

8. Prates LPCS, Iório MCM. Aclimatização: estudo do reconhecimento de fala em usuários de próteses auditivas. PróFono RAtual Cient 2006;18(3):345-51.

9. Myers S, Palmer CV. Functional and subjective changes over 16 weeks after hearing aid fitting: a case study. Semin Hear. 2005;26(3):140-3.

10. Gatehouse $\mathrm{S}$. The time course and magnitude of perceptual acclimatization to frequency responses: evidence from monoaural fitting of hearing aids. J. Acoust. Soc. Am. 1992;92(3):1258-68.

11. Munro KJ. Reorganization of the Adult Auditory System: perceptual and physiological evidence from monaural fitting of hearing Aids. Trends Amplif. 2008; 12(3):245-70.

12. Humes LE, Wilson DL, Barlow NN, Garner C. Changes in hearing-aid benefit following 1 or 2 years of hearing-aid use by older adults. J Speech Lang Hear Res. 2002;24(4):772-82.
13. Gatehouse S, Killion MH. Hearing AID brain rewiring accommodation time. Hear Inst. 1993; 44(10):29-32.

14. Reber MB, Kompis M. Acclimatization in first-time hearing aid users using three different fitting protocols. Auris Nasus Larynx. 2005;32(4):345-51.

15 Willot JF. Physiological plasticity in the auditory system and its possible relevance to hearing aid use, deprivation effects and acclimatization. Ear Hear. 1996;17(3):66-77.

16. Philibert B, Collet L, Vesson JF, Veuillet E. Intensity-related performance are modified by long-term hearing aid use: a functional plasticity? Hear Res. 2002; 165(2):142-51.

17. Turner CW. et al. A review os past research on changes in hearing aid benefit over the time. Ear Hear. 1996;17(3):14-28.

18. Caporali AS, Silva JA. Reconhecimento de fala no ruído em jovens e idosos com perda auditiva. Revs Bras Otorrinolaringol. 2004;70(4):525-32.

19. Smoorenburg GF. Speech reception in quiet and in noisy: conditions by individuals with noise induced hearing loss in relation to their tone audiogram. J. Acoust. Soc. Am. 1992;91(1):421-37.

20. Middelweerd MJ, Festen JM, Plomp R. Difficulties with speech intelligibility in noise in spite of a normal pure-tone audiogram. Audiology. 1990;29(1):1-7.

21. Henriques MO. Limiares e índices percentuais de reconhecimento de sentenças no ruído, em campo livre, para indivíduos adultos [Dissertação]. Santa Maria (RS): Universidade Federal de Santa Maria; 2006. 